\title{
The Determinants Affecting On Outsourcing of Internal Audit Function: Finance Companies Special Reference to Kandy Urban Area
}

\author{
Amarajeewa HGLN ${ }^{1}$, Dedunu $\mathrm{HH}^{2}$, Bandara, AADP ${ }^{2}$ \\ Undergraduate Department of Accountancy \& Finance, Rajarata University of Sri Lankal, \\ Lecturer, Department of Accountancy \& Finance, Rajarata University of Sri Lanka ${ }^{2}$
}

\begin{abstract}
The purpose of this research is to investigate the factors those affecting in outsourcing of internal audit function of Sri Lankan Finance companies. The independent variables are independence, internal audit quality, management support, expertise knowledge and cost. The dependent variable is internal audit outsourcing. According to the literature five hypotheses were developed. The sample consists with fifty management level and operational level employees of Finance companies which outsourcing internal audit function in Kandy urban area. A questionnaire was used to identify the factors affected for outsourcing of internal audit function in finance companies. In this research twenty one dimensions have used in questionnaire which developed using five point Likert scale ranging from "Strongly Disagree" (1) to "Strongly Agree" (5). Statistical Package for Social Sciences was used to analyze the data.. Different analyze tools are used in this research to measure the relationship between independent variables and dependent variable Such as reliability testing, descriptive statistics, correlation analysis and multiple regression analysis. Researcher builds descriptive hypotheses to identify the impact of independent variables on the dependent variable. Researcher tested hypotheses and could identify three variables are significantly impact on the dependent variable. They were internal audit quality, expertise knowledge and cost.
\end{abstract}

Key Words: Finance Companies, Internal Audit Function, Management and Operational Level, Outsourcing, Sri Lanka,

\section{Introduction}

This research provides insights into Sri Lankan Finance companies internal audit outsourcing practices regarding specially Kandy urban area. In particular, this study aims to extend the internal audit outsourcing literature by investigating whether independence, internal audit quality, management support, expertise knowledge and cost are determinants of the internal audit outsourcing phenomenon. Furthermore, if there is a relationship between these determinants and the propensity to outsource the internal audit function, this research aims to explore which factors influence the decision-making around outsourcing the internal audit functions.

This research provides an in-depth analysis of determinants of internal audit outsourcing in Sri Lankan Finance Companies. This research helps to identify the significance of the outsourcing of internal audit function in Sri Lankan finance companies. Some benefits can be achieved through the internal audit outsourcing. Such as independence, more skills, cost effectiveness, new techniques, time management. Findings of the research will provide guidelines for Sri Lankan Finance Companies to decide whether to outsource or not the internal audit service.

\section{Statement Of The Problem}

There are number of reasons why organizations make the decision to outsource. Most reasons will fall into the categories of cost efficiency, the need for specialized technical expertise, the need to build capacity and to improve the quality of the audit. Once management, together with the oversight body, has made the decision to outsource or co-source internal audit, then the first important consideration is the assignment of ownership responsibilities within the management structure, followed by documenting these responsibilities in the Internal Audit charter. Management, under the oversight of the Audit Committee, should then decide the choice of service provider. Such a service provider should ideally be a reputable firm with stronger denials that will meet the needs of the organization.

Scarce resources defined as the company lacks of knowledge or people to maintain their company function. Therefore, most of the firms prefer to outsource their function rather than establishing an in-house development. Sometime firms have to face the challenge of retaining skilled employees within their company. Furthermore, in order to enhance the effectiveness of risk management, control, and governance processes of firms, internal audit function is needed to add value to an organization. Therefore it is currently essential requirement to identify determinants affecting on outsourcing of internal function. 


\section{Objectives Of The Research}

To investigate the factors those affecting in outsourcing of internal audit function of Sri Lankan finance companies.

To examine the relationship between the factors and internal audit outsourcing.

\section{Review Of Literature}

The study here will discuss about the foundation and studies related to the topic. Theoretical foundation and past studies are reviewed and further expressed. A proposed conceptual framework is developed to examine the relation between the independent variables and dependent variable. This section is willing to describe research thoroughly on various literatures on internal audit function, independent variables such as independency, internal audit quality, management support, expertise knowledge, cost and review the dependent variable internal audit outsourcing.

According to The Institute of Internal Auditors (Definition of internal auditing, 2013), internal auditing is an independent, objective assurance and consulting activity designed to add value and improve an organization's operations. Carey et al. (2006) described outsourcing as a service that provided or surrendered to external parties. Barac et al. (2009) defined internal audit outsourcing as an approach where the functions were executed by the outsider apart from the organization that will provide the benefits of cost advantage, effectiveness and efficiency of the operations and profession gain. Internal audit outsourcing is an activity where the firms employ or appoint independent public accounting firms and other professionals to execute the works that have not been done by internal auditors traditionally and a study found out the increasing importance of internal auditing (Zhang \& Gao, 2012; Ebaid, 2011).

According to Mihret and Yismaw, 2007, the study stated that internal audit helps to improve the organization by enhancing the audit effectiveness and quality which will eventually help the management to recognize the problems and thus achieve the objectives of the particular organization. Prawitt, Sharp and Wood, 2011, also stated that accounting risk can be diminished when the internal audit function is outsourced to external third parties and it will be able to reduce the risk of fraudulent financial reporting. Although most of the studies have supported that outsourcing of internal audit will bring benefits into the organization, yet Muqattash (2011), says that by having the internal audit within the organizations will have more advantage rather than completely outsource to third parties.

According to literature (Ahmad and Taylor, (2009), (Hudaib and Haniffa , (2009),( Inua and Abianga (2015), (Kouakou, Boiral and Gendron,(2013), Independence requires integrity and an objective approach to the audit process. Researcher indicated about assessing commitment to independence by internal auditors, exploring auditor independence, International Standard Organization auditing and the construction of trust in auditor independence under these variables. Independence was taken as a variable in studies by the researchers.

According to literature of past researchers (Sawyer, (1995), (Ziegenfus, (2000), (Mihret and Woldeyohannis, (2007), (Gansberghe, (2005), (Walker, (1996), internal audit quality is a most important factor in this study. It is mostly affecting to the effectiveness of the internal audit. There are some factors to determine the internal audit quality. They are scope of service, audit planning, and fieldwork and quality review and audit communication. Internal audit quality was taken as a variable in most of studies by the researchers.

According to literature (Mihret and Woldeyohannis, (2007), management support is also most substantial factor affecting to the audit effectiveness. There are some factors to determine the management support. They are Organizational Setting, Organizational Status and Internal Organization, Organizational Status and Internal Organization.

According to above literature, expertise knowledge is the skills, competencies, experiences and abilities of the auditors which engaging to perform the outsourcing of the internal audit function. Expertise knowledge was taken as a variable in studies by the researchers.

According to previous studies (Jie et.al. (2013), (Barac and Motubatse, (2010), (Dorasamy, (2010), (Alaghehband, Rivard, Wu and Goyette, (2011), (Yasseen, (2011), (Sharma and Subramaniam, (2005) cost is always the key factor that will affect and influence the decision of an organization whether to outsource or not. Cost was taken as a variable in most of studies by the researchers like as other variables. Most of the researchers found that the outsourcing of the internal audit function is more suitable than the maintaining internal audit department in the organizations considering the factor of the cost.

According to literature (Caplan, Janvrin and Kurtenbach,(2007), (Abbott ,(2003), (Papageorgiou, Yassen and Padia , (2012),(Carey, Subramaniam and Chua,(2006),(Barac, and Motubatse, (2010),(Zhang and Gao, (2012,( Ebaid, (2011),(Mihret and Woldeyohannis, (2007),(Prawitt, Sharp, and Wood, (2011),(Muqattash ,(2011) outsourcing of the internal audit function was taken as the dependent variable in most of studies by the researchers. 


\subsection{Study Design}

\section{Methodology}

This study aims to investigate the factors those affecting in outsourcing of internal audit function of Sri Lankan finance companies. This study conducts quantitative data collection technique to test a general theory by numerical data. Data will be collected through questionnaires. The questionnaires will be offered to management and operational level employees who are working in finance companies which outsourcing the internal audit function in Kandy urban area. (The target respondents are 15 management level employees and 35 operational level employees of finance companies which they have educational background about internal audit and in the relevant audit field.)

\subsection{Conceptual Framework.}

Figure 1; Conceptual Framework

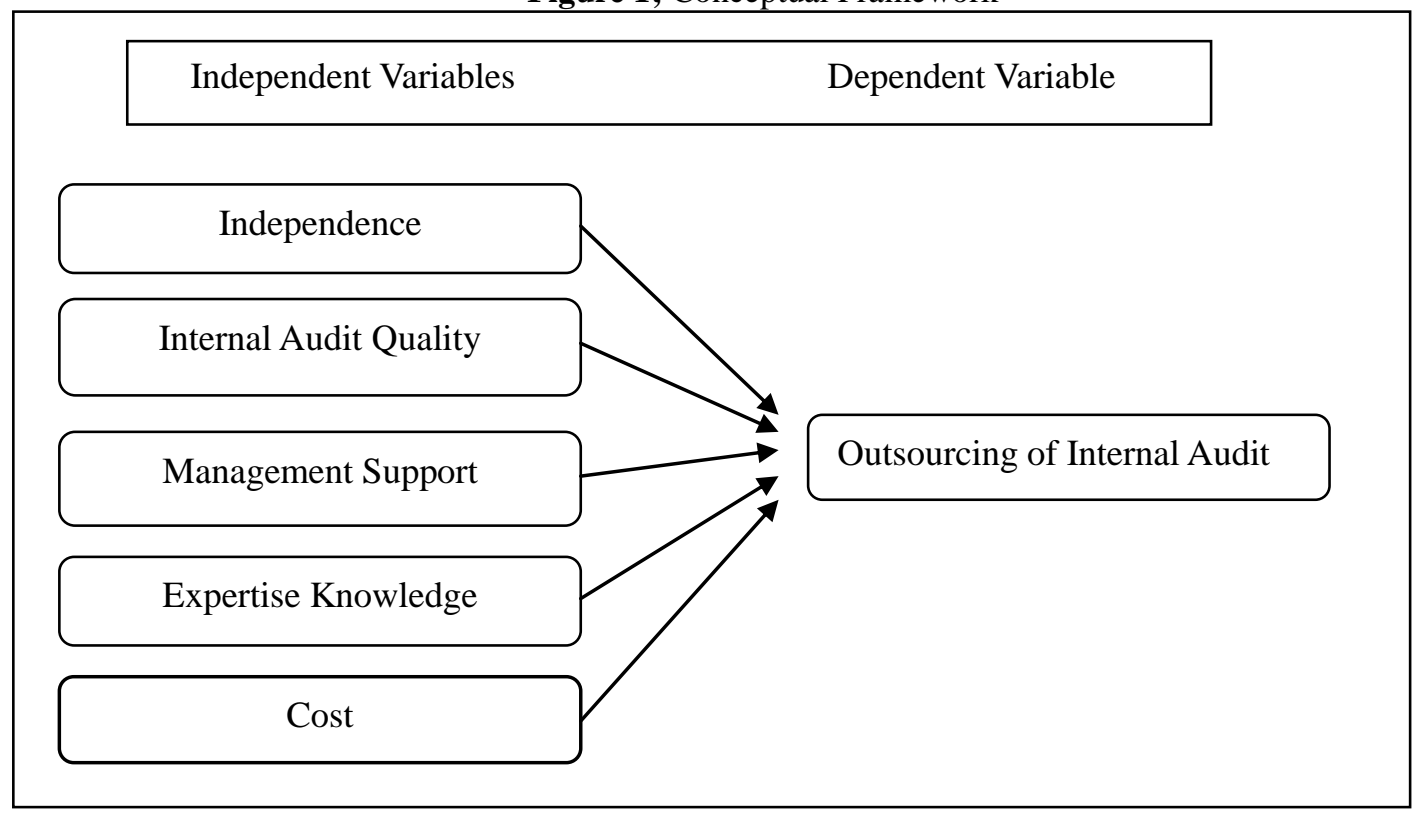

\subsection{Hypotheses}

H1: Independency of the internal audit function is affecting to the degree of internal audit outsourcing

H2: The higher internal audit quality of the internal audit function is lead to maintain the degree of internal audit outsourcing.

H3: Management support of the firm is affecting to the outsourcing of internal audit function.

H4: Expertise knowledge of the auditors who engage in the outsourcing of internal audit function is affecting to internal audit outsourcing.

H5: The cost of the internal will lead to outsourcing of internal audit function.

\subsection{Population and Sample}

There are forty seven Finance companies are currently operating in Sri Lanka as per the Annual Report of Central Bank of Sri Lanka in 2014. The population consists with all employees in management and operational level in finance companies which outsourcing internal audit function are located in Kandy urban area. The sample for this particular study is fifty management (15) and operational (35) level employees in finance companies which outsourcing internal audit function in Kandy urban area. That research purpose investigates seven finance companies which outsourcing internal audit function in Kandy urban area in Sri Lanka.

\subsection{Data Collection}

The study obtains primary data through questionnaires and interviews wherever applicable and possible. Primary data were collected through the questionnaires at the management level and operational level employees in Sri Lankan Finance Sector. A questionnaire consist a set of questions presented to a respondent for his or her answer. Under this study questionnaires were issued to the management level and operational level employees of finance companies in Kandy urban area. 


\subsection{Techniques of Data Analysis}

Data analysis is carried out with the aid of the Statistical Package for Social Sciences (SPSS). This analysis included Reliability Testing, Descriptive Statistics, Correlation Analysis, and Multiple Regression.

\subsection{Reliability Analysis}

\section{Results And Discussion}

Table 1; Reliability Test

\begin{tabular}{|l|c|c|}
\hline \multicolumn{1}{|c|}{ Variable } & No. of Items & Cronbach's Alpha \\
\hline Independence & 3 & 0.726 \\
\hline Internal Audit quality & 4 & 0.708 \\
\hline Management support & 3 & 0.744 \\
\hline Expertise knowledge & 3 & 0.723 \\
\hline Cost & 3 & 0.714 \\
\hline Outsourcing of internal audit & 5 & 0.761 \\
\hline
\end{tabular}

Source; survey data, 2015

Independence, internal audit quality, management support, expertise knowledge, cost and Outsourcing of internal audit indicate the values of more than 0.70 values. Overall Cronbach"s Alpha Value of the questionnaire indicates the values of more than 0.70 values. Therefore all of these independent and dependent variables are in the accepted level

\subsection{Descriptive Analysis}

Table 2; Descriptive Analysis

\begin{tabular}{|l|c|c|c|}
\hline \multirow{2}{*}{ Variables } & $\mathrm{N}$ & Mean & Std. Deviation \\
\cline { 2 - 4 } & Statistic & Statistic & \multicolumn{1}{l|}{ Statistic } \\
\hline Independence & 50 & 4.03 & 0.44 \\
\hline Internal audit quality & 50 & 3.94 & 0.50 \\
\hline Management support & 50 & 4.07 & 0.45 \\
\hline Expertise knowledge & 50 & 3.96 & 0.56 \\
\hline Cost & 50 & 3.77 & 0.60 \\
\hline Outsourcing internal audit function & 50 & 4.08 & 0.51 \\
\hline
\end{tabular}

Source; survey data, 2015

The mean and standard deviation of each variable was computed. The mean values for all the variables are in the range of 3.77to 4.08. This shows that the variables are more towards agreed. Meanwhile, the standard deviation is less than one which indicates that there is less data deviation from mean.

\subsection{Correlation Analysis}

Table 3; Correlations Analysis

\begin{tabular}{|c|c|c|c|c|c|}
\hline variables & $\begin{array}{c}\text { Independ } \\
\text { ency }\end{array}$ & $\begin{array}{c}\text { Internal Audit } \\
\text { Quality }\end{array}$ & $\begin{array}{c}\text { Management } \\
\text { Support }\end{array}$ & $\begin{array}{c}\text { Expertise } \\
\text { knowledge }\end{array}$ & $\begin{array}{c}\text { Cost } \\
\text { Outsourcing of Internal Audit }\end{array}$ \\
$\begin{array}{c}0.462 \\
\text { Correlation Sig. }\end{array}$ & 0.001 & 0.570 & 0.202 & 0.581 & 0.656 \\
0.000 & 0.159 & 0.000 & 0.000 \\
\hline
\end{tabular}

Source; survey data, 2015

\section{Independency and Outsourcing of Internal Audit Function}

According to Table, the correlation between independency and internal audit outsourcing is 0.462 , indicates a positive relationship between these two variables. The p-value is less than 0.05.It indicates that the correlation coefficient is statistically significant.

\section{Internal Audit Quality and Outsourcing of Internal Audit Function}

Based on Table, the correlation between internal audit quality and internal audit outsourcing is 0.570 . Thus, there is a positive relationship between these two variables. The p-value with less than 0.05 indicates a significant correlation coefficient.

\section{Management Support and Outsourcing of Internal Audit Function}

According to Table, the correlation between management support and internal audit outsourcing is 0. 202, indicates a positive relationship between these two variables. The p-value is more than 0.05 , indicates that the correlation coefficient is not statistically significant. 


\section{Expertise Knowledge and Outsourcing of Internal Audit Function}

Based on Table, the correlation between expertise knowledge and internal audit outsourcing is 0.581 . Thus, there is a positive relationship between these two variables. The p-value with less than 0.05 indicates a significant correlation coefficient.

\section{Cost and Outsourcing of Internal Audit Function}

According to Table, the correlation between cost and internal audit outsourcing is 0.656 , indicates a strong positive relationship between these two variables. The $\mathrm{p}$-value is less than 0.05 indicates that the correlation coefficient is statistically significant. According to the correlation analysis result, only Independence, Internal audit quality, Expertise knowledge and Cost variables have significant association with the internal audit outsourcing. Therefore those variables were forwarded to the regression analysis. The hypothesis based on management support is automatically rejected.

\subsection{Multi Linear Regression}

For the Multiple Regression Analysis, only significant variables in correlation analysis are used. According to correlation analysis independency, internal audit quality, expertise knowledge and cost were statistically significant variables.

Table 4; Model summary

\begin{tabular}{|c|c|c|c|}
\hline $\begin{array}{c}\text { Mode } \\
\text { I }\end{array}$ & $\mathrm{R}$ & $\mathrm{R}$ Square & Adjusted R Square \\
\hline 1 & 0.821 & 0.674 & 0.645 \\
\hline \multicolumn{4}{|c|}{ Source; survey data, 2015} \\
\hline
\end{tabular}

$\mathrm{R}$ square value of the research is 0.674 . This means that $67.4 \%$ of the variation of dependent variable (internal auditor outsourcing) can be explained by the four independent variables (independence, internal audit quality, expertise knowledge and cost). However, 32.6\% (100\%-67.4\%) of the variation of the dependent variable is not explained in the research, which means $32.6 \%$ variation of dependent variable is explained by the exogenous variables.

\subsection{ANOVA Test}

Table 5; ANOVA table

\begin{tabular}{|l|r|r|r|r|c|}
\hline \multicolumn{1}{|c|}{ Model } & Sum of Squares & df & Mean Square & F & Sig. \\
\hline Regression & 8.639 & 4 & 2.160 & 23.286 & 0.000 \\
Residual & 4.174 & 45 & 0.093 & & \\
Total & 12.813 & 49 & & & \\
\hline
\end{tabular}

Source; survey data, 2015

Overall fit of the regression model is satisfactory. Because P-value of ANOVA is .000 which value less than 0.05 . Therefore statistical evidence is sufficient to say model is strong enough to predict Outsourcing of Internal function.

\subsection{Regression Coefficients}

Table 6; Regression Coefficients table

\begin{tabular}{|c|c|c|c|c|c|}
\hline \multirow[b]{2}{*}{ variables } & \multicolumn{2}{|c|}{ Unstandardized Coefficients } & \multirow{2}{*}{$\frac{\text { Standardizes Coefficients }}{\text { Beta }}$} & \multirow[b]{2}{*}{$\mathrm{t}$} & \multirow[b]{2}{*}{ Sig. } \\
\hline & $B$ & Std.Error & & & \\
\hline Intercept & -0.019 & 0.466 & 0 & -0.041 & 0.968 \\
\hline Independency & 0.149 & 0.115 & 0.131 & 1.297 & 0.201 \\
\hline Internal Audit Quality & 0.282 & 0.104 & 0.281 & 2.706 & 0.010 \\
\hline Expertise knowledge & 0.211 & 0.092 & 0.234 & 2.293 & 0.027 \\
\hline Cost & 0.413 & 0.077 & 0.484 & 5.331 & 0.000 \\
\hline
\end{tabular}

Source; survey data, 2015

According to Table, internal audit quality, expertise knowledge and cost are significantly affecting internal audit outsourcing with significant value of less than 0.05 . Independency is not significantly influencing the decision to outsource internal audit with significant value of more than 0.05 .

\subsection{Unstandardized Coefficients}

Unstandardized coefficient is used to build regression equation of this research. An equation is formed as follows: 
Where,

$$
Y=-0.019+0.282 X_{1}+0.211 X_{2}+0.413 X_{3}+€
$$

$\mathrm{Y}=\mathrm{DV}=$ Outsourcing of internal audit

$\mathrm{X}_{1}=\mathrm{IV} 1$ = Internal Audit Quality

$\mathrm{X}_{2}=\mathrm{IV} 2=$ Expertise knowledge

$\mathrm{X}_{3}=\mathrm{IV} 3=$ Cost

Independence, internal audit quality, expertise knowledge, cost have positive relationships with internal audit outsourcing. But independency is not a significant variable. Therefore it is not included in regression model.

\subsection{Results of the study}

There are five hypotheses in this study. Therefore under this study researcher was trying to come over the conclusion relating to the hypotheses.

H1: Independency of the internal audit function is directly affecting to the degree of internal audit outsourcing.

According to the regression result, standardized coefficient of independency was 0.131 and $p=0.201$, hence study did not reject H0: Independency of the internal audit function is not directly affecting to the degree of internal audit outsourcing.

H2: The higher internal audit quality of the internal audit function is lead to maintain the degree of internal audit outsourcing.

According to the regression result, unstandardized regression coefficient of internal audit quality was 0.282 and $\mathrm{p}=0.010$, hence study rejected $\mathrm{H} 0$ and accepted $\mathrm{H} 1$ : The higher internal audit quality of the internal audit function. Accordingly there is a statistical significant relationship between internal audit quality and internal audit outsourcing. It indicates that $1 \%$ increase of internal audit quality will lead to increase internal audit outsourcing by $0.282 \%$.

H4: Expertise knowledge of the auditors who engage in the outsourcing of internal audit function is directly affecting to internal audit outsourcing.

According to the regression result, unstandardized regression coefficient of expertise knowledge was 0.211 and $\mathrm{p}=0.027$ hence study rejected $\mathrm{H} 0$ and accepted H1: Expertise knowledge of the auditors who engage in the outsourcing of internal audit function is directly affecting to internal audit outsourcing. Accordingly there is a statistical significant relationship between expertise knowledge and internal audit outsourcing. It indicates that $1 \%$ increase of expertise knowledge will lead to increase internal audit outsourcing by $0.211 \%$.

H5: The cost of the internal will lead to outsourcing of internal audit function.

According to the regression result, unstandardized regression coefficient of cost was 0.413 and $p=0.000$ hence study rejected $\mathrm{H} 0$ and accepted $\mathrm{H} 1$ : The cost of the internal will lead to outsourcing of internal audit function. Accordingly there is a statistical significant relationship between expertise knowledge and cost. It indicates that $1 \%$ increase of expertise knowledge will lead to increase internal audit outsourcing by $0.413 \%$.

\section{Conclusion And Recommendations}

According to literature five hypotheses are made using the five variables. Based on the findings of Multiple Linear Regression analysis, internal audit quality, expertise knowledge and cost indicate significant influences on internal audit outsourcing. As well as, independency and management support are not the significant factors affecting internal audit outsourcing. Finance companies should pay great attention on the significant factors such as internal audit quality, expertise knowledge and cost while considering decision of internal audit outsourcing. However, for independency and management support, finance companies seem to have paid less attention on these issues.

Normally finance sector organizations are considered as organizations that operate efficiently according to the rules and regulations of the Central Bank of Sri Lanka. Therefore internal audit is very important for finance sector organizations. Finance companies are the one kind of finance sector organization which people go to get different services. People expect quality services form finance companies. The organizations which have a good internal audit system in the organization can go to the success and get more benefits.

After considering above findings, future research is recommended to get more accurate population by increasing the sample size, which will represent a more accurate population. In order to explain the relationship between independent and dependent variables more accurately, future studies are recommended to increase mediating factors. So, future researchers are recommended to investigate deeply on mediating factors for a more accurate and reliable research. Future researchers are highly recommended to perform studies in conducting the researches observing the same variables applying the difference of observations in collecting data. As well as this research studied for only the specific sector. So, it may not be able to determine that outsource the internal audit function is suitable for all the sectors. Therefore future researchers are recommended to imply researches using some several sectors in the study. 


\section{References}

[1]. Abbott, L., Parker, S., Peters, G., \& Rama, D. V. (2013) Audit committee effectiveness and internalaudit outsourcing. Florida.p 2-36

[2]. Barac, K \& Motubatse, K N (2009) Internal audit outsourcing practices in South Africa, Afican Journal of Business Management. University of South Africa. P 1-11

[3]. Caplan,D., Janvrin,D. and Kurtenbach,J. (2007) Internal Audit Outsourcing:An Analysis Of Self-regulation By The Accounting Profession, Research in Accounting Regulation, p.4-31

[4]. Carey, P., Subramaniam, N., \& Chua, W. C. K. (2006). Internal audit outsourcing in Australi. Accounting and Finance 46(1), 11-30.

[5]. Definition of internal auditing. (n.d.). Retrieved March 26, 2013, from The institute of internal auditors website: https://na.theiia.org/standards-guidance/ mandatory-guidance/pages/definition-of-internal-auditing.aspx

[6]. Ebaid, I. E.-S. (2011). Internal audit function: An exploratory study from Egyptian listed firms. International Journal of Law and Management, 53(2)

[7]. IIA. (2013) Managing the outsourced Internal Audit function. White Paper. P 4-10

[8]. Inua, O.I. and Abianga,E.U.,(2015) The Effect of the Internal Audit Outsourcing on Auditor Independence: The Nigerian Experience. Research Journal of Finance and Accounting. P 36-42.

[9]. Jie, A. K., Nam, C. H., Mei, C. K., Khoon, K. L., \& Sheemon, T. (,2013). Determinants of internal audit outsourcig: an empiricalstudy of SMEs in Malaysia. Malaysia: University Tunku Abduk Rahman. p 16-72.

[10]. Mihret, D. G., \& Woldeyohannis, G. Z. (2007) Internal Audit Effectiveness: an Ethiopian public sector case study. Managrial Auditing Journal.p.3-15

[11]. Mihret, D. G., \& Yismaw, A. W. (2007) Internal audit effectiveness: An Ethiopian public sector case study. Managerial Auditing Journal, 22(5),

[12]. Muqattash, R. (2011). The effect of the factors in the internal audit department on the internal auditors objectivity in the banks operating in the United Arab Emirates. Journal of International Management Studies, 6(3)

[13]. Papageorgiou, E., Yasseen,Y. and Padia, N. (2012) Internal audit function: Current status and perception of outsourcing. African Journal of Business Management. p 1-11

[14]. Prawitt, D. F., Sharp, N. Y., \& Wood, D. A. (2011). Internal audit outsourcing and the risk of misleading or fraudulent financial reporting: Did Sarbanes-Oxley get it wrong? Business And Economics--Accounting, 29(4).

[15]. Sharma,D.S., Subramaniam,N. (2005) Outsourcing Of Internal Audit Services In Australian Firms: Some Preliminary Evidence, Asian Academy Of Management Journal Of Accounting And Finance. p 33-50.

[16]. Vottis,T., Abbott, M. and Nellegar,J. (2006) Interenal Audit Outsourcing, Insourcing and Shared Services. Internal Control Task force. P 3-9.

[17]. Zhang, J., \& Gao, S. (2012). How do SMEs build internal audit capabilities? A grounded theory approach. World Review of Business Research, 2(1) 